\title{
Fabrication and Investigation of Mechnical Properties of Al-flyash-SiC Composites
}

\author{
Gurpreet Singh $^{1}$, Khushdeep Goyal ${ }^{1, *}$, Deepak Kumar Goyal ${ }^{2}$ \\ ${ }^{1}$ Department of Mechanical Engineering, Punjabi University, India \\ ${ }^{2}$ Department of Mechanical Engineering, Baba Banda Singh Bahadur Engineering College, India
}

Copyright $(\subset 2015$ by authors, all rights reserved. Authors agree that this article remains permanently open access under the terms of the Creative Commons Attribution License 4.0 International License

\begin{abstract}
The composite materials have received great attention due to their light weight, high performance, environment friendly and wear resistance properties and excellent tribololgical properties over the metals and their alloys. There is a good scope to develop new aluminum based composite material which will further improve these properties. Therefore in this research work, a new aluminum based composite material was successfully fabricated by reinforcing with fly ash and Silicon carbide and its mechanical properties like wear resistance, hardness and tensile strength were investigated.
\end{abstract}

Keywords Composites, Stir Casting, Fabrication, Fly Ash, Wear

\section{Introduction}

Composite materials are able to meet the global demand for light weight, high performance, environmental friendly and wear resistance materials [1]. The composite materials have received great attention due to their excellent tribololgical properties over the metals and their alloys [2-4]. In a metal matrix composite, one constituent is called matrix phase and other is called reinforcing phase. Reinforcing phase is embedded in the matrix to give the desired properties [5].

Fabrication of metal matrix composite has several limitations such as porosity, poor wettability and improper distribution of reinforcement particles. Achieving uniform distribution of reinforcement is very important for the composite [6]. The conventional stir casting is an important processing method for fabrication and is inexpensive and offers wide selection of materials and processing condition. It offers better matrix particle reinforcement due to stirring action of particles into melt [7].

The variables such as composition of matrix, reinforced particles distribution, weight percentage affect the mechanical properties of the composite but weight percentage of reinforcement has more effect on the mechanical properties like wear resistance, hardness, tensile strength etc. Fly ash is one of the residues generated in the coal [8]. Silicon carbide is a compound of silicon and carbon with a chemical formula $\mathrm{SiC}$. Silicon carbide was originally produced by a high temp electrochemical reaction of sand and carbon. Any acids or alkalis or molten salts up to $800^{\circ} \mathrm{C}$ do not attack silicon carbide [10]. It is reported in the literature that the silicon carbide and fly ash particle size and its volume fraction also significantly affect the wear and friction properties of composites [9]. Senapati et al. [10] studied the extensive literature review on the usage of fly as a reinforcement agent for different matrix. Fly ash was used in molten metal and cast because it can reduce the overall weight and density due to low density of fly ash [11].

The aim of the present study is to investigate the wear rate, hardness, tensile strength (breaking load) of stir cast Al6061 with $5 \mathrm{wt} \%, 10 \mathrm{wt} \%$ of fly ash and $5 \mathrm{wt} \%, 10 \mathrm{wt} \%$ of silicon carbide. The wear test was performed on pin on disc type of wear testing machine. Micro wicker hardness tester and universal tensile tester were used for hardness measurement and tensile strength (breaking load) measurement respectively.

\section{Experimentation}

The aluminium(6061)-fly ash (5\%, 10\%), aluminium(6061)-SiC (5\%, 10\%) and aluminium(6061)-fly ash-SiC (5\%-10\%) composites were prepared by stir casting route. First of all, $400 \mathrm{gm}$ of commercially aluminium(6061) was melted in the electric induction furnace at $760 \mathrm{deg}$. C in a graphite crucible and then $(5,10) \mathrm{wt} \%$ of fly ash were added to the $\mathrm{Al}$ melt for production of two different composites. The fly ash particles were preheated up to 300 deg. $\mathrm{C}$ in muffle furnace for two hours to remove the moisture. Then the melt was stirred using a mild steel stirrer. Fly-ash particles were added to the melt at the time of formation of vortex in the melt due to stirring. The melt temperature was maintained at 760-770 deg. C during the 
addition of the particles. Then the melt was casted in a clay graphite crucible.

After that another $400 \mathrm{gm}$ of aluminium(6061) was melt in the furnace at $760 \mathrm{deg}$. $\mathrm{C}$ and $(5,10) \mathrm{wt} \%$ of $\mathrm{SiC}$ were added to the $\mathrm{Al}$ melt for the production of two different composites. The $\mathrm{SiC}$ were preheated up to $500 \mathrm{deg}$. $\mathrm{C}$ in muffle furnace to remove the moisture content. Then mild steel stirrer was used for stirring the melt. $\mathrm{SiC}$ particles were added in molten aluminium. Then the melt was casted in a clay graphite crucible.

After the fabrication of aluminium-fly ash and aluminium-SiC composites, the final composites are fabricated by melting the $400 \mathrm{gm}$ aluminium (6061) in the furnace and mix the $\mathrm{SiC}$ and fly ash. The mixture was preheated at $500 \mathrm{deg}$. $\mathrm{C}$ in muffle furnace to remove moisture. Mixture was added to the molten aluminium at 760 deg. $\mathrm{C}$ and mild steel stirrer was used for stirring. Then the melt was casted in a clay graphite crucible.

The wear characteristics and friction of $\mathrm{Al}-(5,10) \mathrm{wt} \%$ fly ash, Al- $(5,10) \mathrm{wt} \% \mathrm{SiC}$ and $\mathrm{Al}-(5,10) \mathrm{wt} \% \mathrm{SiC}-(5,10) \mathrm{wt} \%$ fly ash composites were evaluated using Pin on Disc wear testing machine. For this, cylindrical specimens of $6 \mathrm{~mm}$ diameter and $25 \mathrm{~mm}$ length were prepared from the cast Alfly ash, Al-SiC and Al-SiC-fly ash composites. Test was performed under $2 \mathrm{~N}$ load and $300 \mathrm{rpm}$ for 10 minutes. The Optical microscopy was done for all the samples.

The hardness testing and tensile strength (breaking load) were carried out $\mathrm{Al}-(5,10) \mathrm{wt} \%$ fly ash, $\mathrm{Al}-(5,10) \mathrm{wt} \% \mathrm{SiC}$ and $\mathrm{Al}-(5,10) \mathrm{wt} \% \mathrm{SiC}-(5,10) \mathrm{wt} \%$ fly ash composites. The hardness of the samples was determined by Micro Vicker hardness testing machine. The tensile strength of the samples was determined by Universal tensile testing machine.

\section{Result and Discussion}

\subsection{Results of Wear Behavior and Variation of Frictional Force}

In the figures below, the wear behavior and variation of frictional force of $\mathrm{Al}+(5 \%)$ Fly ash is shown:

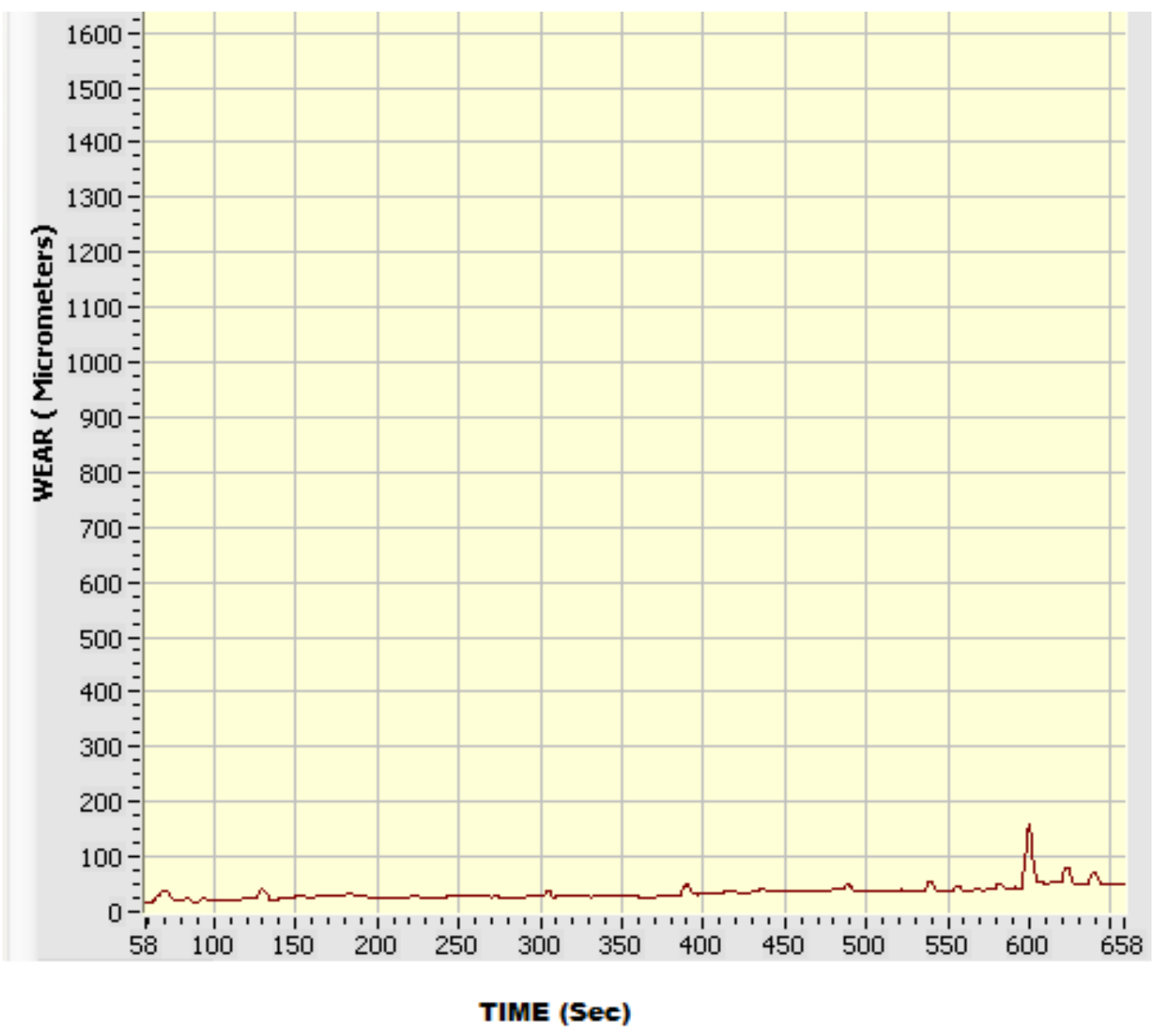

Figure 1(a). Wear behavior of for $\mathrm{Al}+(5 \%)$ Fly ash composite at $300 \mathrm{rpm}$ and at $20 \mathrm{~N}$ 


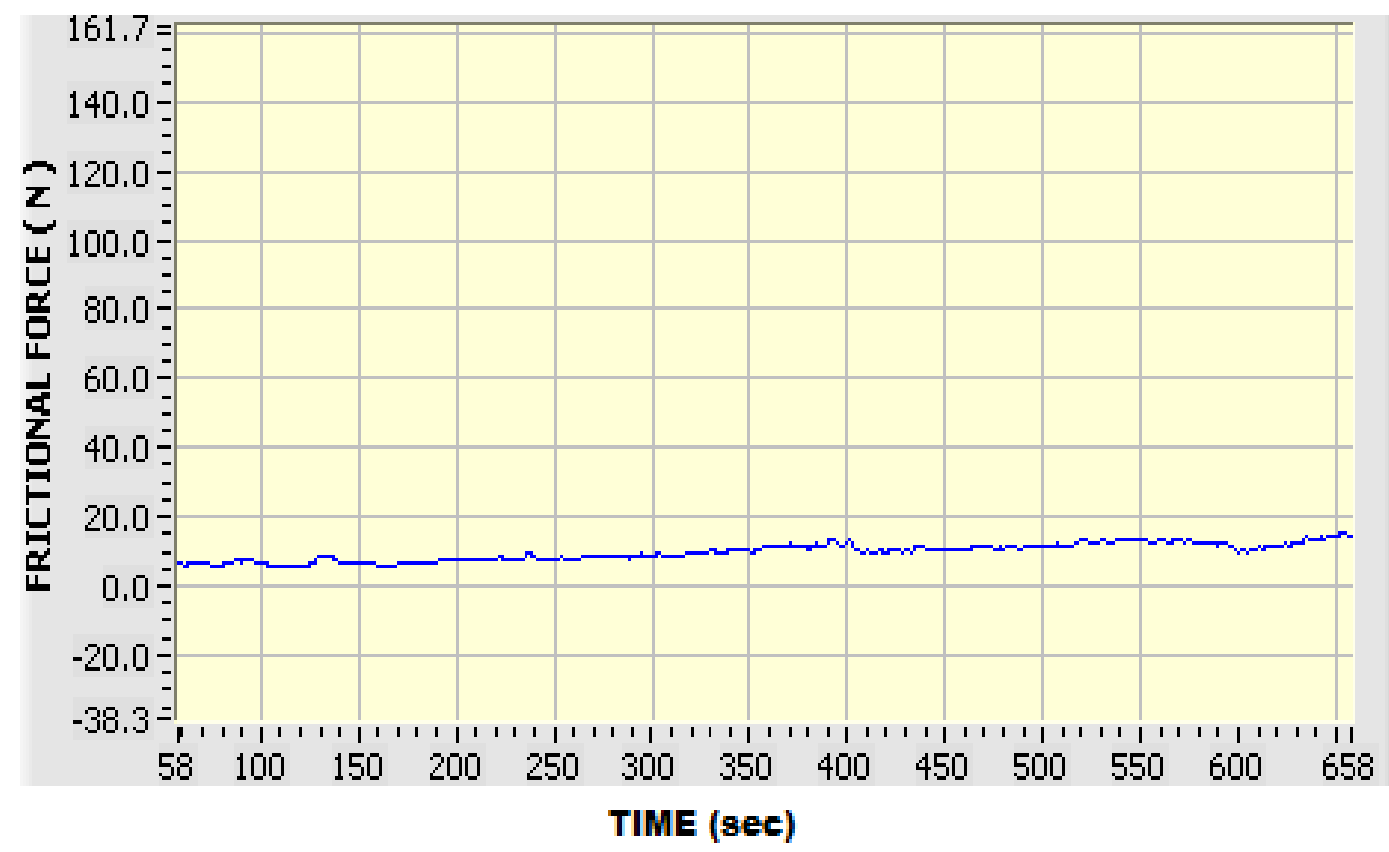

Figure 1 (b). Variation of Frictional force for $\mathrm{Al}+(5 \%)$ fly ash at $300 \mathrm{rpm}$ and at $20 \mathrm{~N}$.

In figures below, the wear behavior and variation of frictional force of $\mathrm{Al}+(10 \%)$ Fly ash is shown:

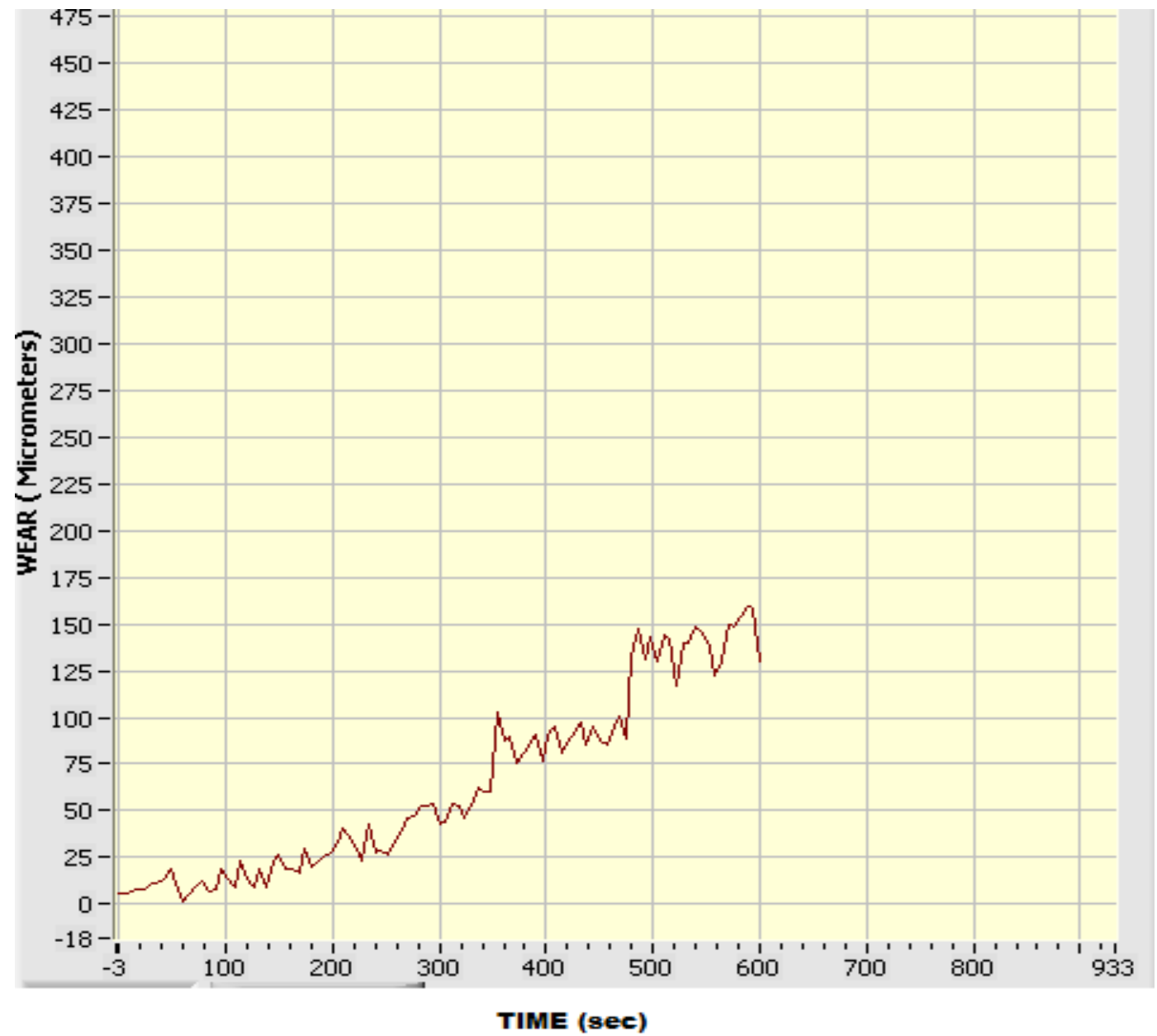

Figure 2 (a). Wear behavior of $\mathrm{Al}+(10 \%)$ Fly ash composite at $20 \mathrm{~N}$ load at $300 \mathrm{rpm}$. 


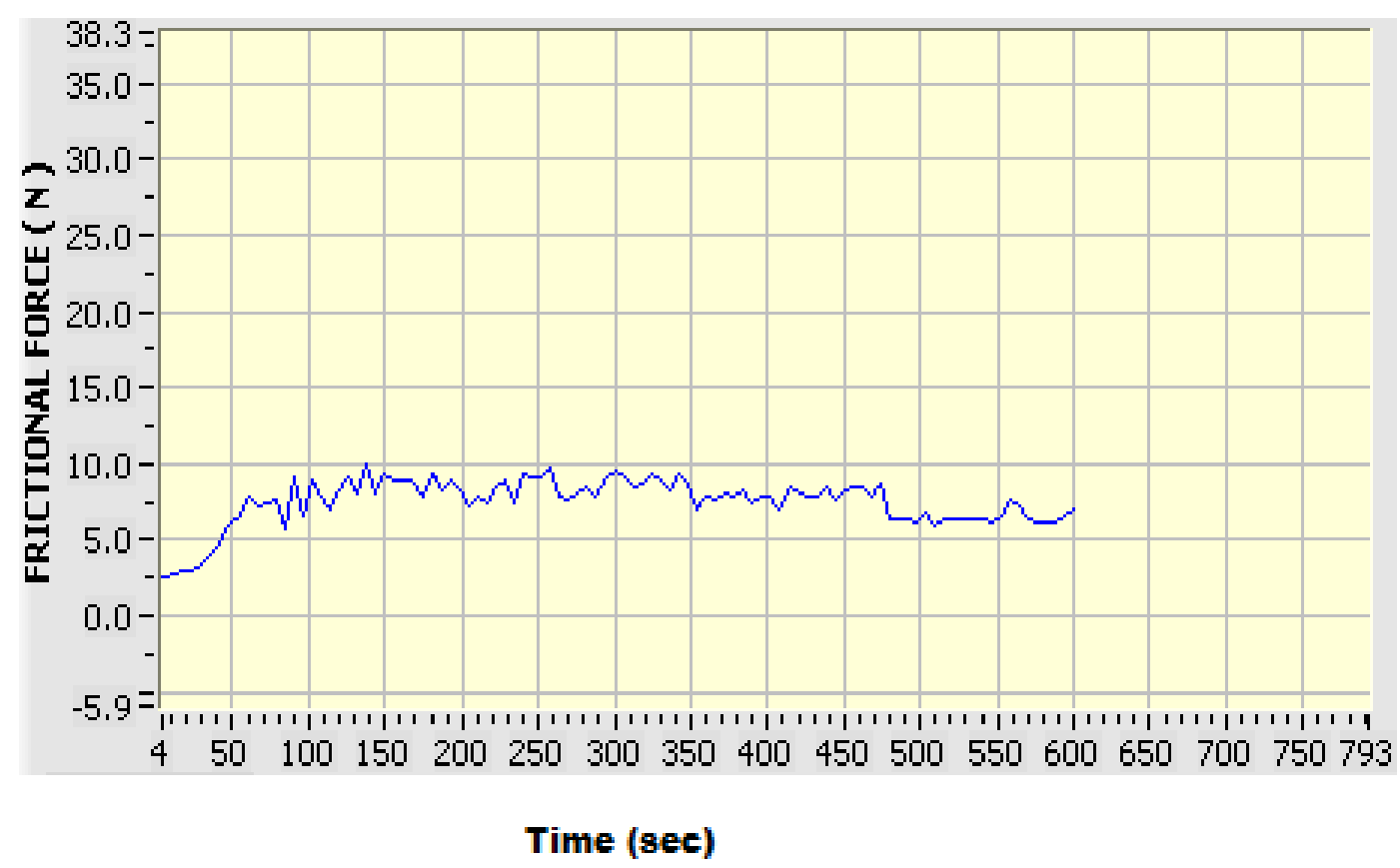

Figure 2 (b). Variation of Frictional force for $\mathrm{Al}+(10 \%)$ Fly ash composite at $20 \mathrm{~N}$ load at $300 \mathrm{rpm}$

In figures below, the wear behavior and variation of frictional force of $\mathrm{Al}+(5 \%) \mathrm{SiC}$ is shown:

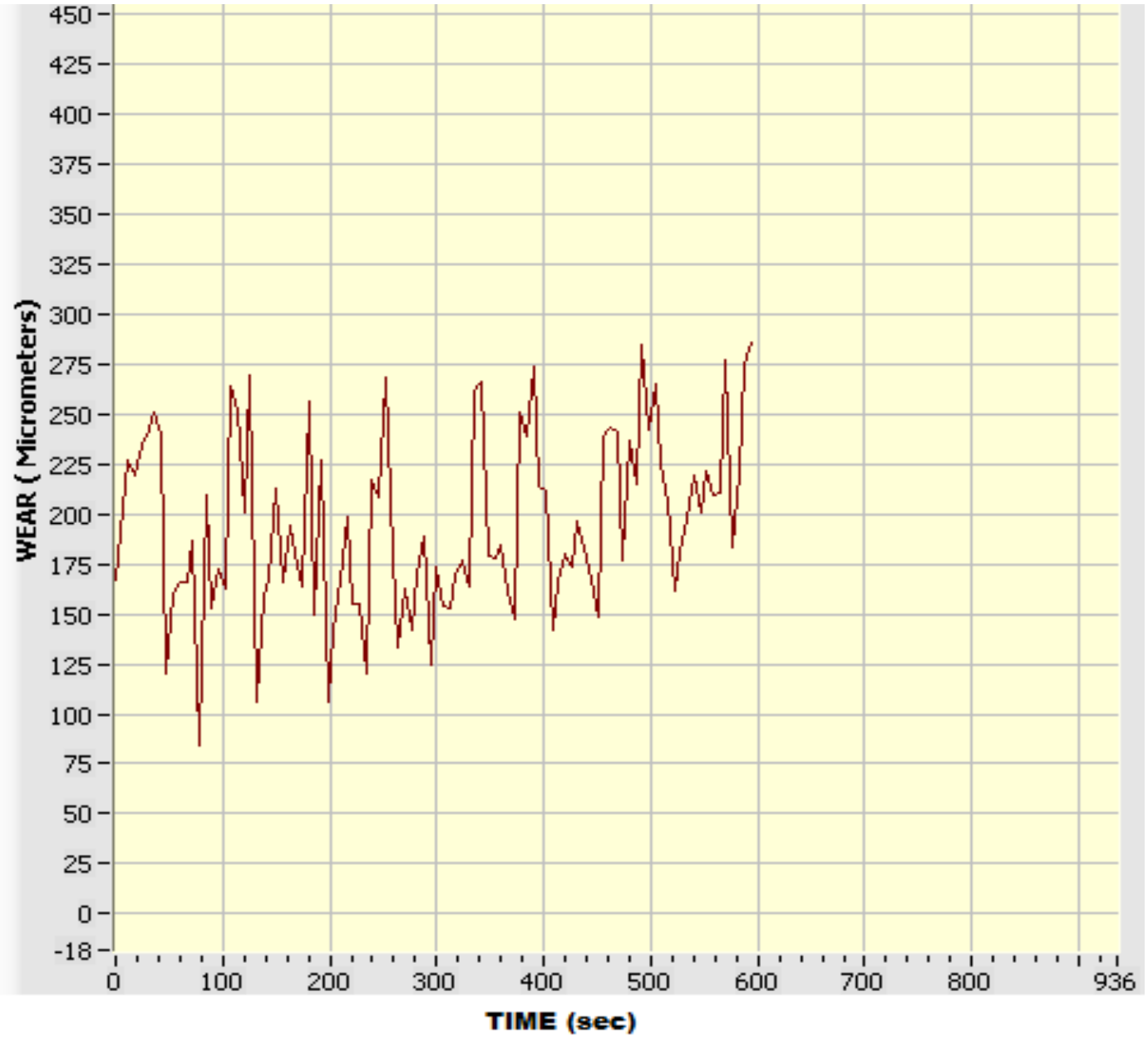

Figure 3(a). Wear behavior of for $\mathrm{Al}+(5 \%) \mathrm{SiC}$ composite at $300 \mathrm{rpm}$ and at $20 \mathrm{~N}$ 


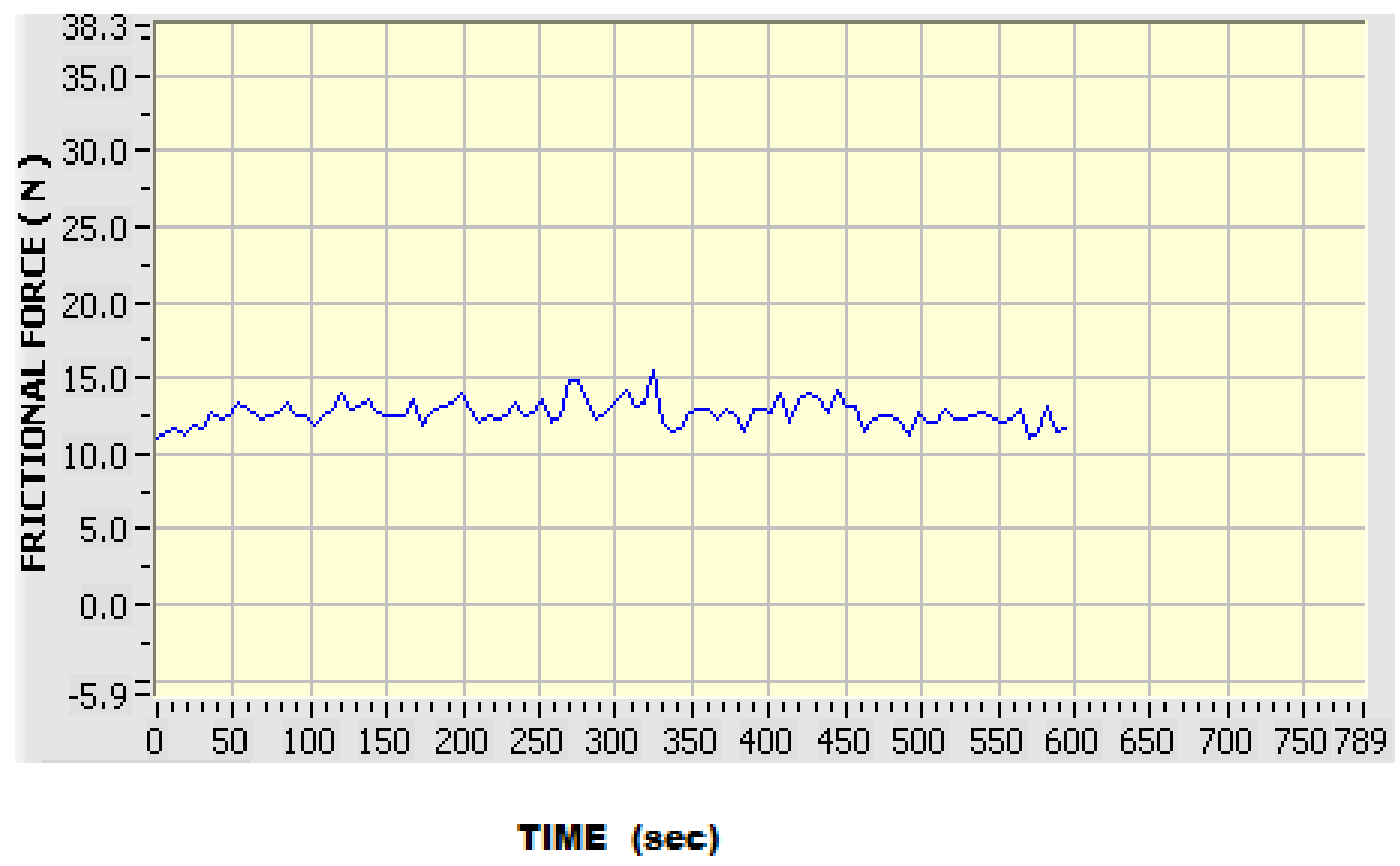

Figure 3 (b). Variation of Frictional force for $\mathrm{Al}+(5 \%) \mathrm{SiC}$ at $300 \mathrm{rpm}$ and at $20 \mathrm{~N}$.

In figures below, the wear behavior and variation of frictional force of $\mathrm{Al}+(10 \%) \mathrm{SiC}$ is shown:

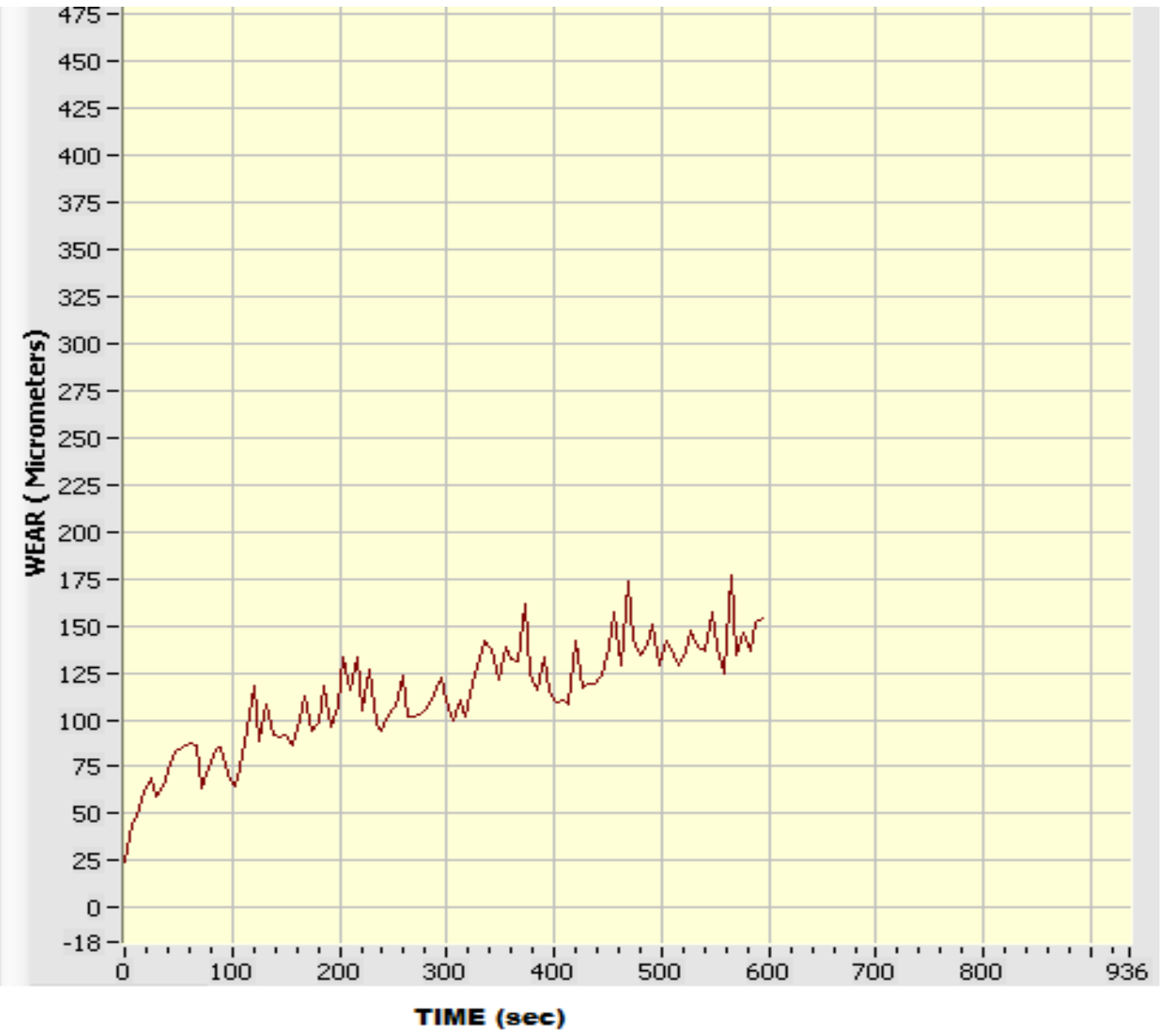

Figure 4(a). Wear behavior of for $\mathrm{Al}+(10 \%) \mathrm{SiC}$ composite at $300 \mathrm{rpm}$ and at $20 \mathrm{~N}$ 


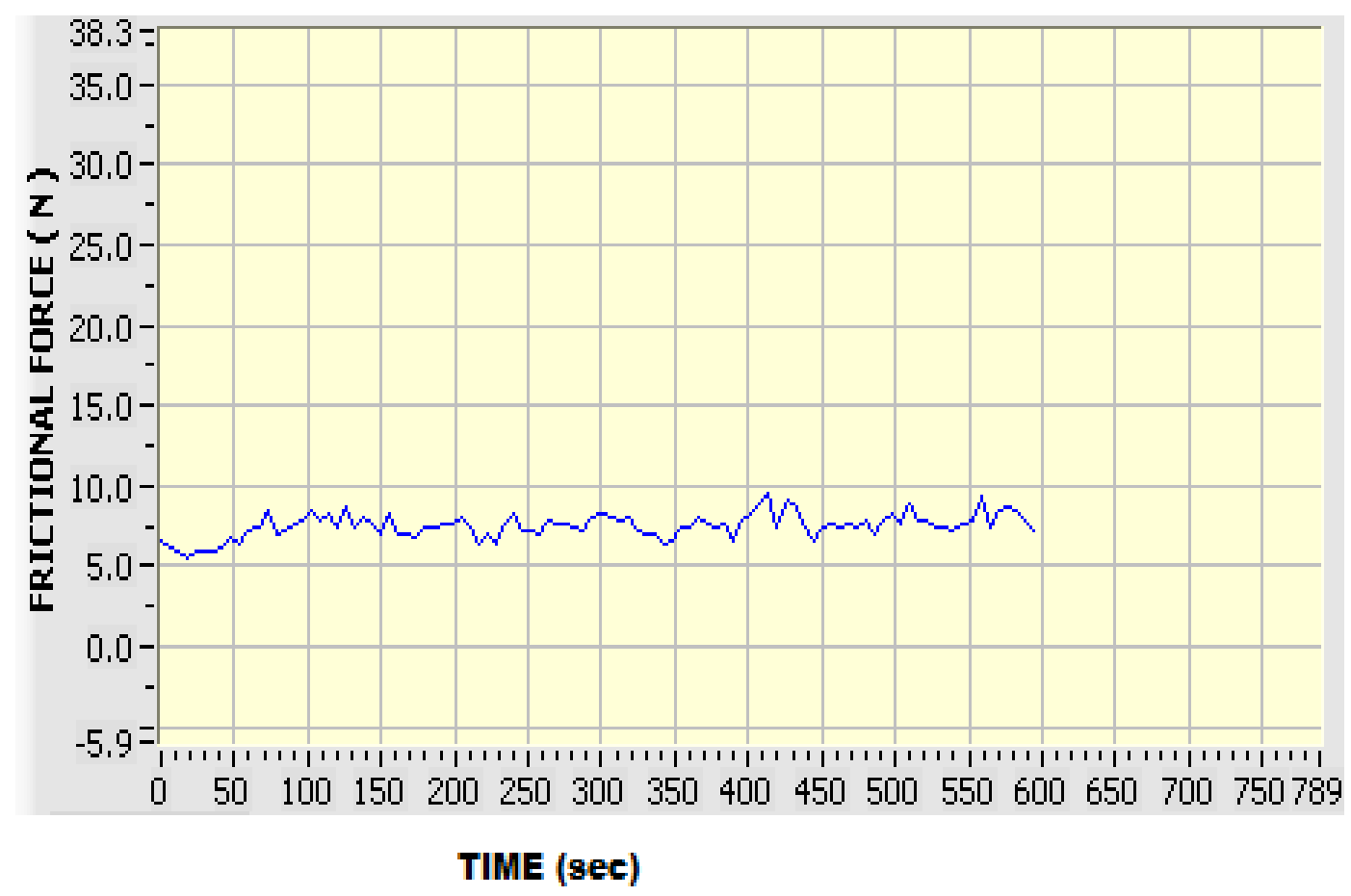

Figure 4 (b). Variation of Frictional force for $\mathrm{Al}+(10 \%) \mathrm{SiC}$ at $300 \mathrm{rpm}$ and at $20 \mathrm{~N}$.

In figures below, the wear behavior and variation of frictional force of $\mathrm{Al}+(5 \%) \mathrm{Fly}$ ash $+(5 \%) \mathrm{SiC}$ is shown:

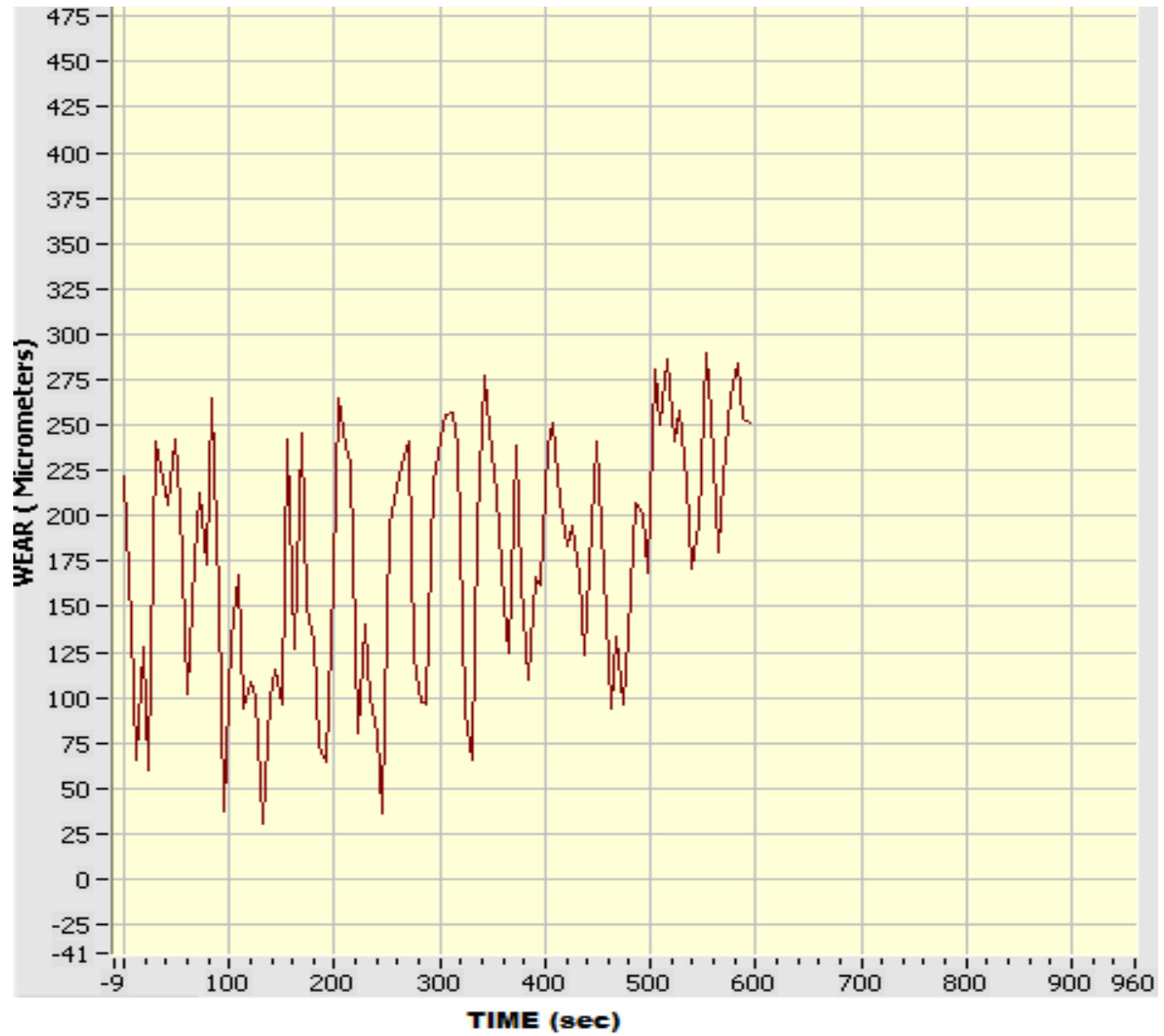

Figure 5(a). Wear behavior of for $\mathrm{Al}+(5 \%)$ Fly ash $+(5 \%) \mathrm{SiC}$ composite at $300 \mathrm{rpm}$ and at $20 \mathrm{~N}$ 


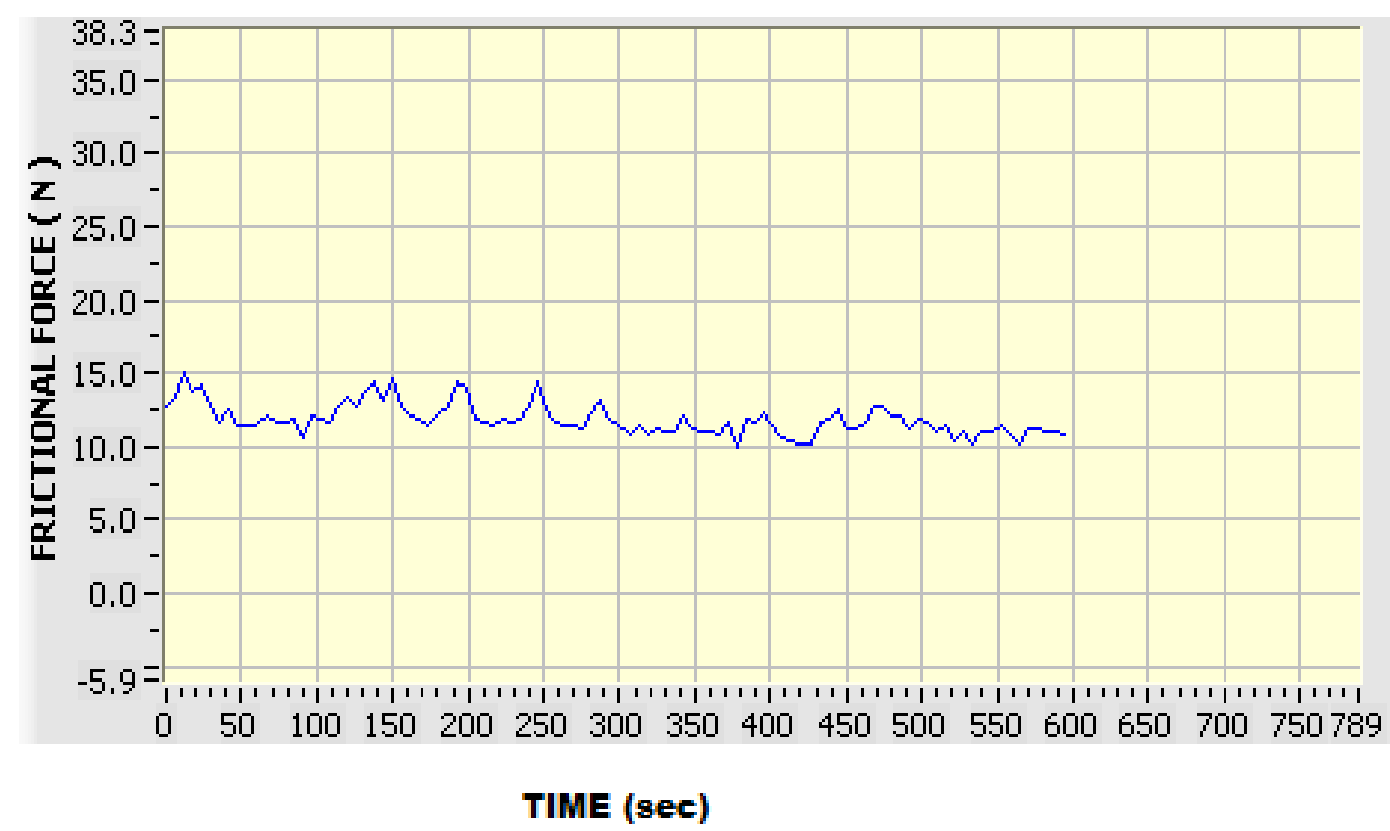

Figure 5 (b). Variation of Frictional force for $\mathrm{Al}+(5 \%)$ fly ash $+(5 \%) \mathrm{SiC}$ at $300 \mathrm{rpm}$ and at $20 \mathrm{~N}$.

In figures below, the wear behavior and variation of frictional force of $\mathrm{Al}+(10 \%) \mathrm{Fly}$ ash $+(10 \%) \mathrm{SiC}$ is shown:

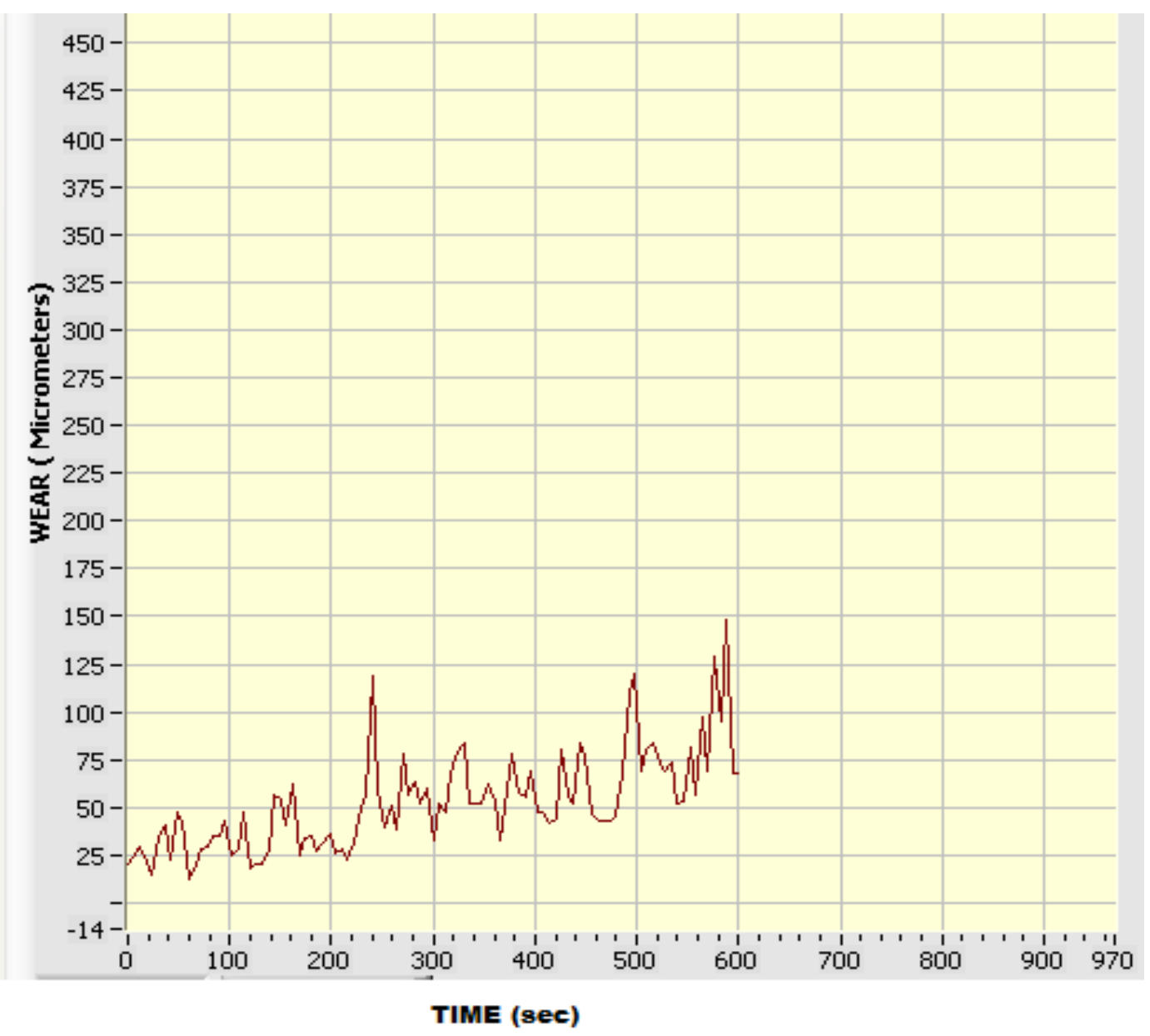

Figure 6(a). Wear behavior of for $\mathrm{Al}+(10 \%) \mathrm{Fly}$ ash $+(10 \%) \mathrm{SiC}$ composite at $300 \mathrm{rpm}$ and at $20 \mathrm{~N}$ 


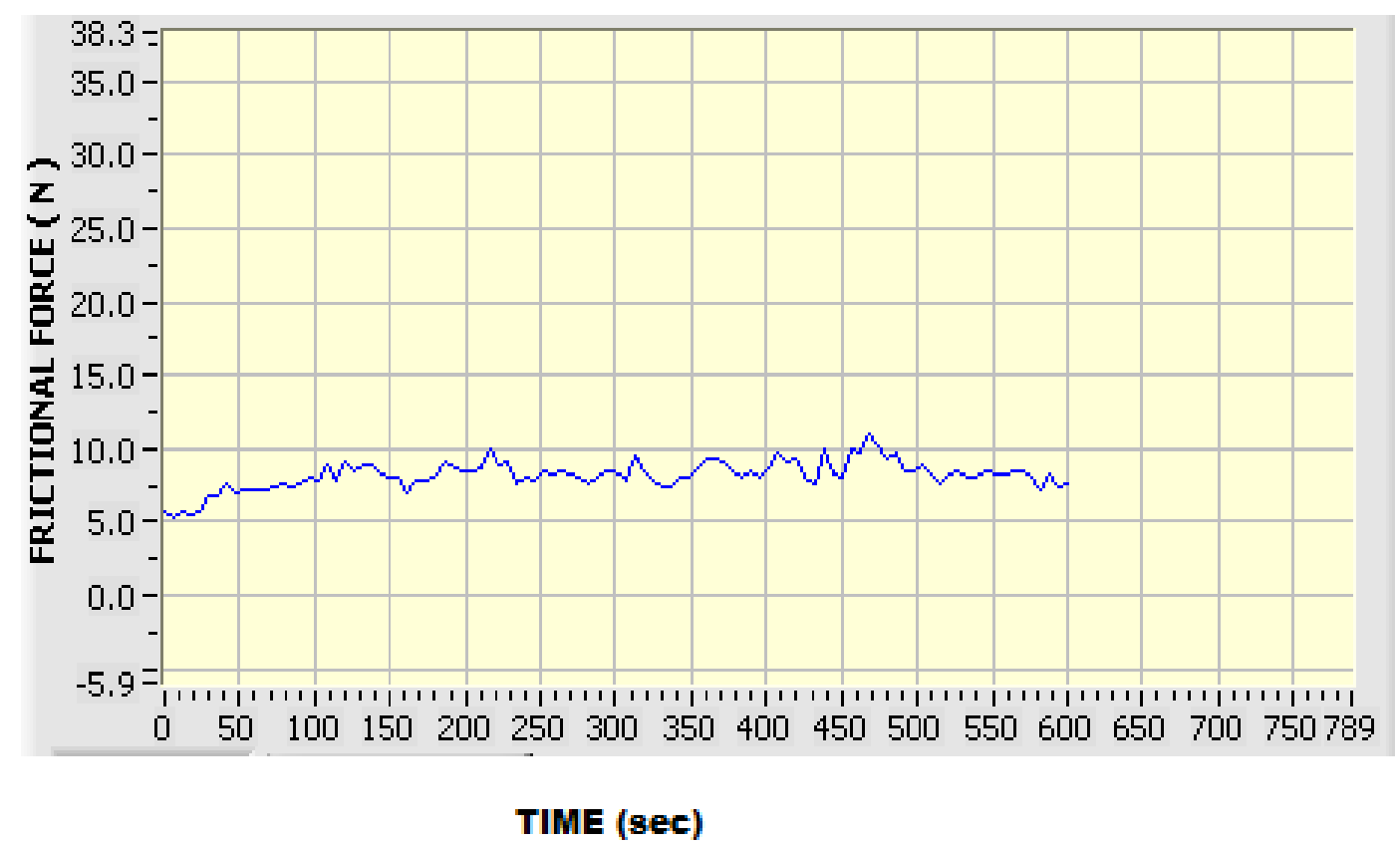

Figure 6 (b). Variation of Frictional force for $\mathrm{Al}+(10 \%)$ fly ash $+(10 \%) \mathrm{SiC}$ at $300 \mathrm{rpm}$ and at $20 \mathrm{~N}$.

The figures [1(a), 1(b), 2(a), 2(b)] shown above, clearly indicate that the wear rate had increased significantly and frictional force was decreased with the increase in the percentage of fly-ash at $300 \mathrm{rpm}$ and $20 \mathrm{~N}$ load.

The figure [3(a), 3(b), 4(a), 4(b)] shown above, clearly indicate that the wear rate and frictional force had decreased with the increase in the percentage of $\mathrm{SiC}$ at $300 \mathrm{rpm}$ and 20 $\mathrm{N}$ load.

The figure [5(a), 5(b), 6(a), 6(b)] shown above, clearly indicate that the wear rate and frictional force had decreased with the increase in the percentage of $\mathrm{SiC}$ and fly ash at 300 rpm and $20 \mathrm{~N}$ load.

It clearly shows that increase in percentage of reinforcement decreases the wear rate and variation of frictional forces. $\mathrm{Al}+\mathrm{fly}$ ash $+\mathrm{SiC}$ composites had less wear rate as compared to single reinforced composites like $\mathrm{Al}+$ fly ash, $\mathrm{Al}+\mathrm{SiC}$.

\subsection{Results of Weight Loss of Samples during Wear Testing}

Table 1. Weight loss of Al+ Fly ash Composites

\begin{tabular}{|c|c|c|c|}
\hline Sample Name & $\begin{array}{c}\text { Initial } \\
\text { Weight (gm) }\end{array}$ & Final Weight(gm) & $\begin{array}{c}\text { Weight } \\
\text { Loss(gm) }\end{array}$ \\
\hline $\begin{array}{c}\mathrm{Al}+5 \% \text { Fly } \\
\text { ash }\end{array}$ & 1.8501 & 1.8498 & 0.0003 \\
\hline \begin{tabular}{c}
$\mathrm{Al}+\begin{array}{c}10 \% \text { Fly } \\
\text { ash }\end{array}$ \\
\hline
\end{tabular} & 1.4966 & 1.4955 & 0.0011 \\
\hline
\end{tabular}

Table 2. Weight loss of $\mathrm{Al}+\mathrm{SiC}$ Composites

\begin{tabular}{|c|c|c|c|}
\hline $\begin{array}{c}\text { Sample } \\
\text { Name }\end{array}$ & $\begin{array}{c}\text { Initial Weight } \\
(\mathrm{gm})\end{array}$ & $\begin{array}{c}\text { Final } \\
\text { Weight(gm) }\end{array}$ & $\begin{array}{c}\text { Weight } \\
\text { Loss }(\mathrm{gm})\end{array}$ \\
\hline $\begin{array}{c}\mathrm{Al}+5 \% \\
\mathrm{SiC}\end{array}$ & 1.9625 & 1.9588 & 0.0037 \\
\hline $\begin{array}{c}\mathrm{Al}+10 \% \\
\mathrm{SiC}\end{array}$ & 2.2537 & 2.2403 & 0.0134 \\
\hline
\end{tabular}


Table 3. Weight loss of $\mathrm{Al}+\mathrm{SiC}+$ fly ash Composites

\begin{tabular}{|c|c|c|c|}
\hline Sample Name & Initial Weight $(\mathrm{gm})$ & Final Weight $(\mathrm{gm})$ & Weight Loss(gm) \\
\hline $\mathrm{Al}+5 \% \mathrm{SiC}+5 \%$ fly ash & 2.9843 & 2.9792 & 0.0051 \\
\hline $\mathrm{Al}+10 \% \mathrm{SiC}+10 \%$ fly ash & 2.9388 & 2.9366 & 0.0022 \\
\hline
\end{tabular}

Tables 1, 2 and 3 clearly show that with the increase in $\mathrm{wt} \%$ of reinforcement in $\mathrm{Al}+\mathrm{fly}$ ash and $\mathrm{Al}+\mathrm{SiC}$ composites, the weight loss was increased but in case of $\mathrm{Al}+\mathrm{SiC}+$ fly ash composites there were decrease in the weight loss.

\subsection{Results of Hardness Measurement}

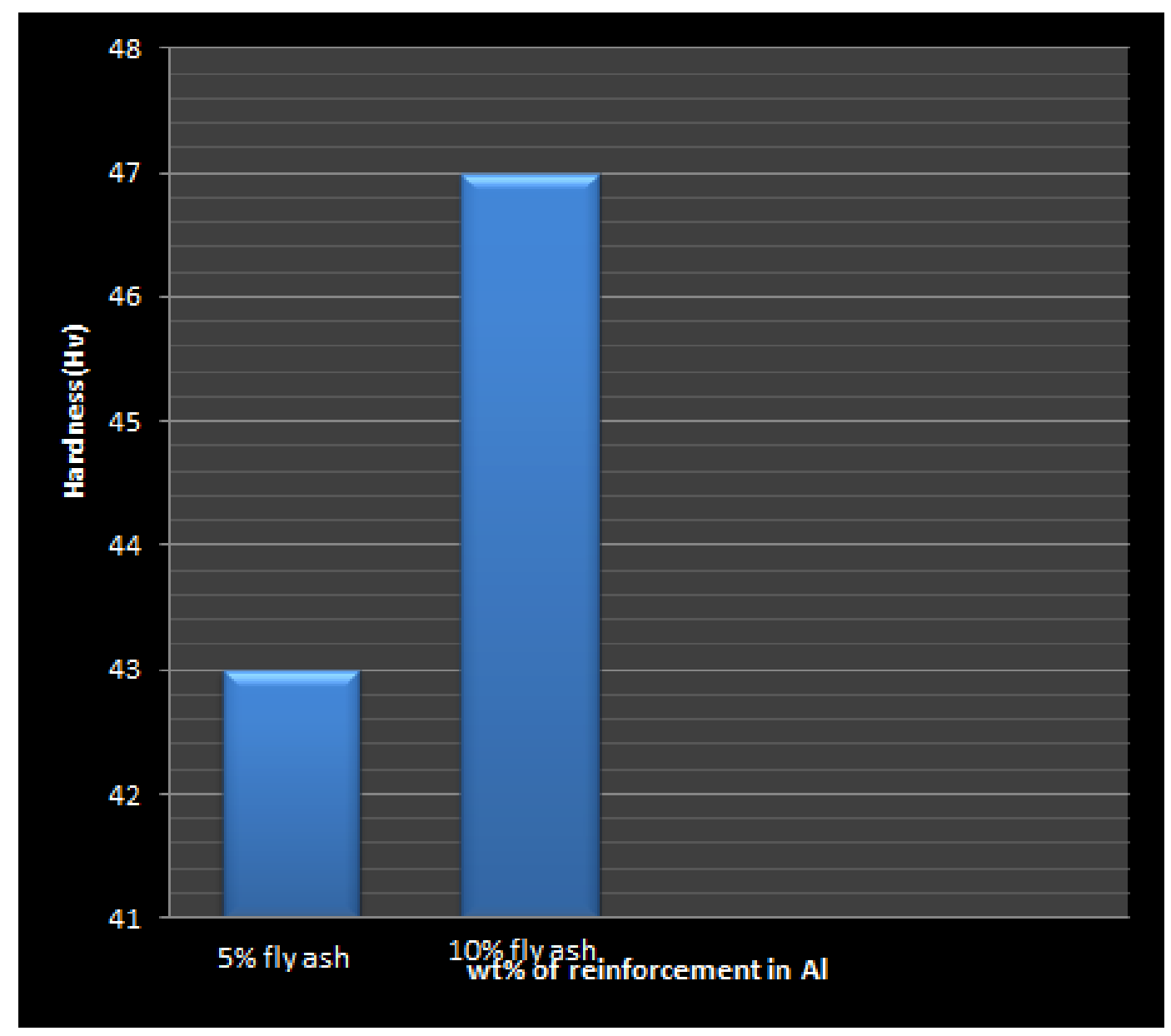

Figure 7. Hardness of Al+fly ash composites 


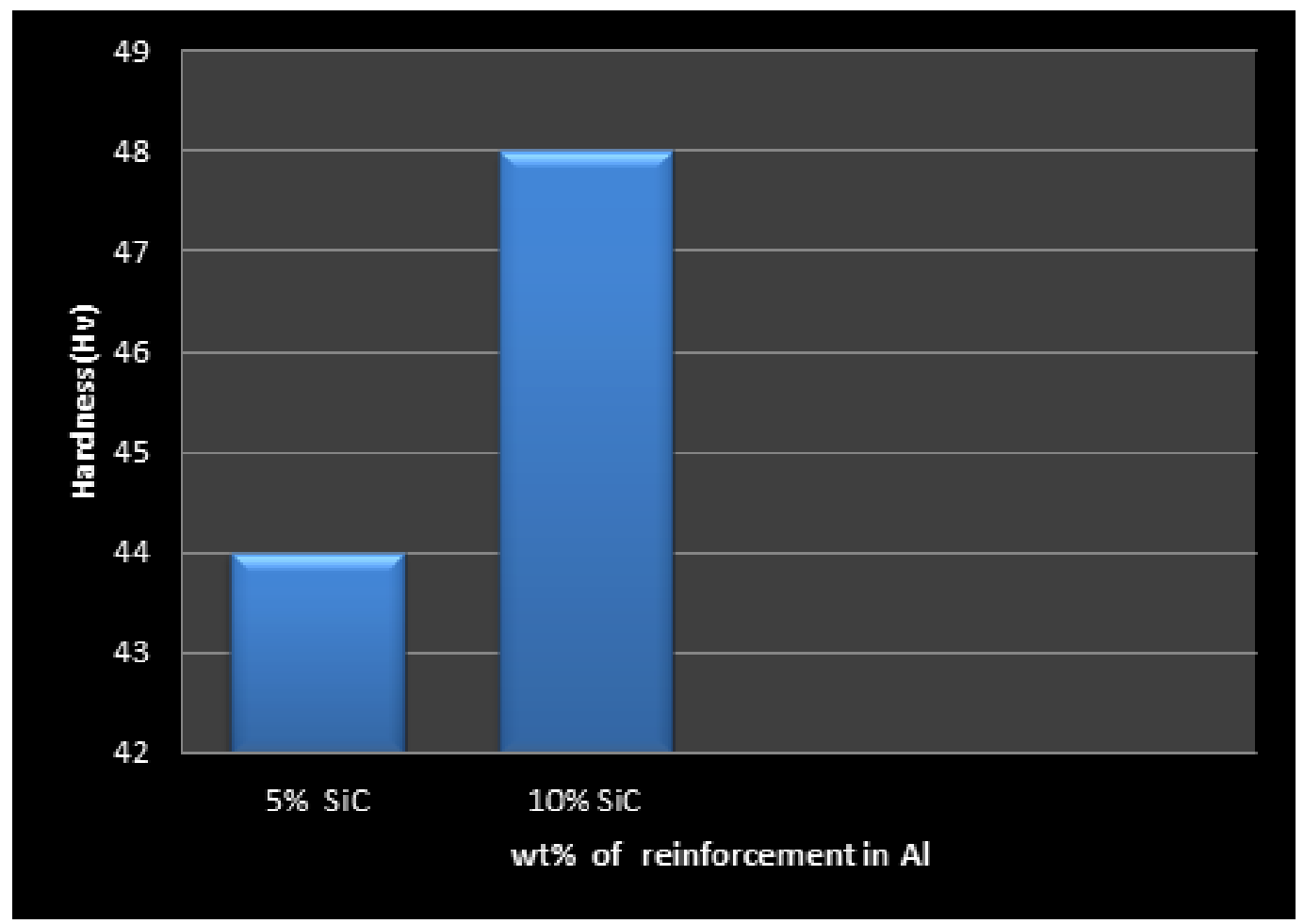

Figure 8. Hardness of $\mathrm{Al}+\mathrm{SiC}$ composites

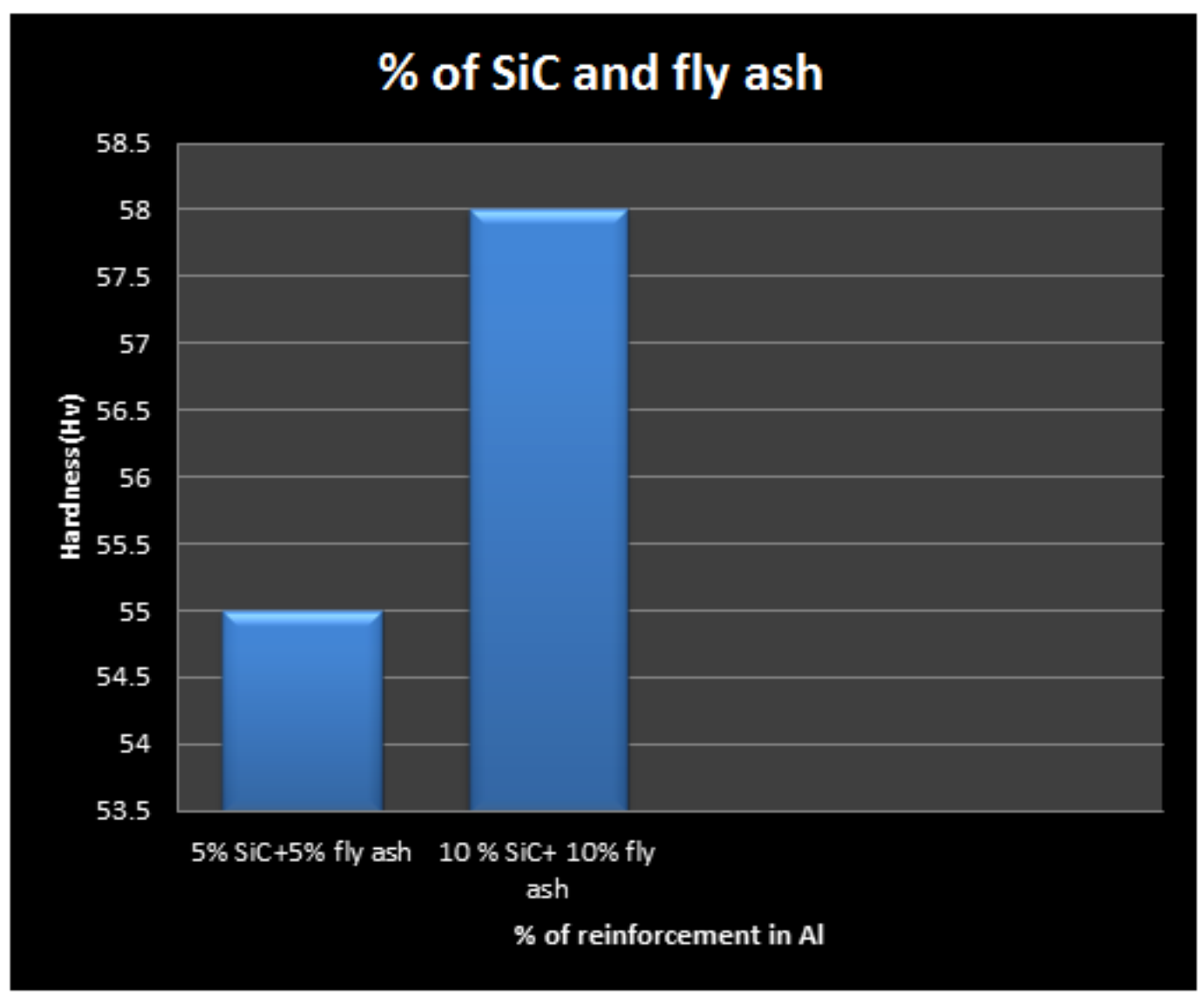

Figure 9. Hardness of $\mathrm{Al}+\mathrm{fly}$ ash $+\mathrm{SiC}$ composites

Figures 7 and 9 clearly show that when fly ash content is increased the hardness is increased and figure 9 clearly shows that $\mathrm{Al}+\mathrm{SiC}+\mathrm{fly}$ ash composites have more hardness than $\mathrm{Al}+\mathrm{SiC}$ and $\mathrm{Al}+$ fly ash composites. 
Results of hardness clearly indicate that reinforcement has high effect on hardness and $\mathrm{Al}+\mathrm{SiC}+\mathrm{fly}$ ash composites are harder than $\mathrm{Al}+$ fly ash and $\mathrm{Al}+\mathrm{SiC}$ composites.

\subsection{Results of Tensile Strength Measurement}

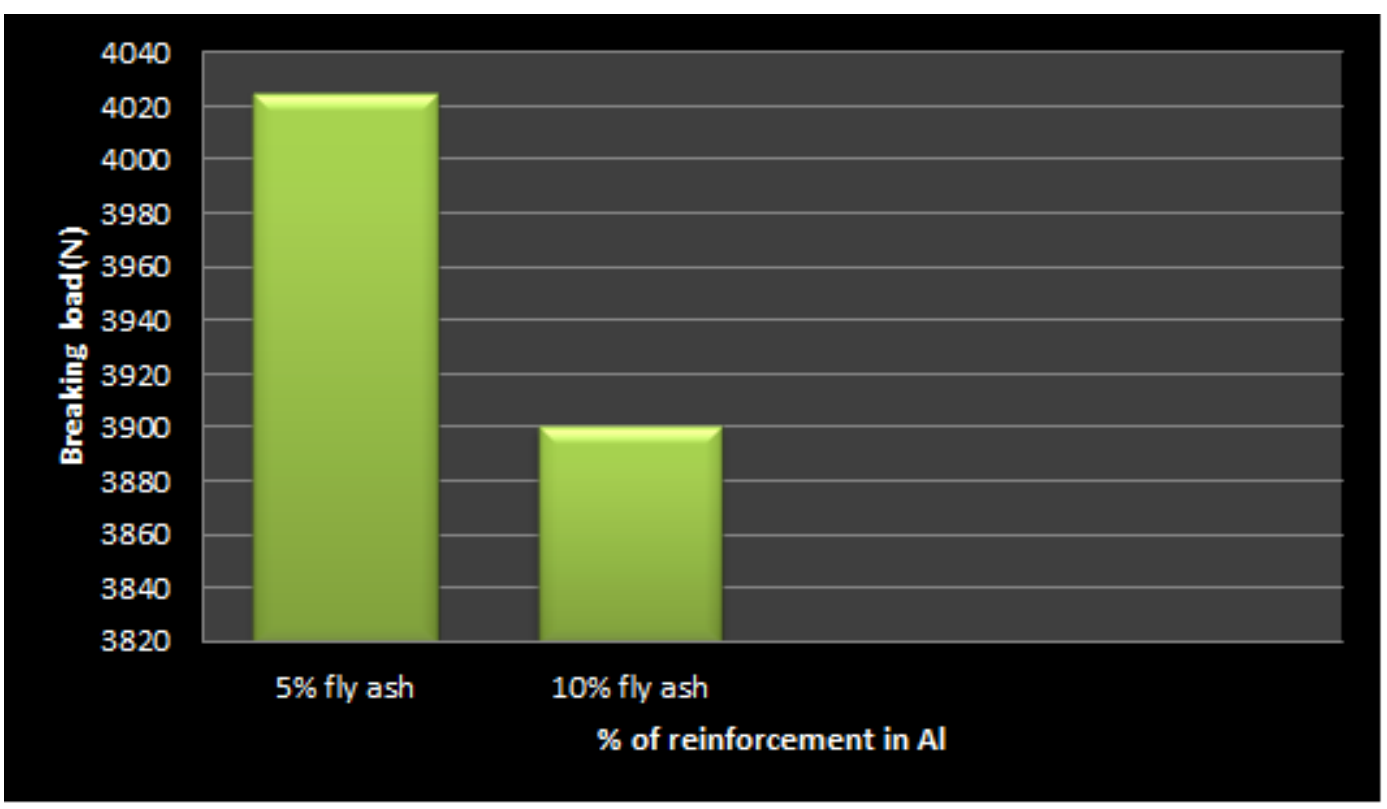

Figure 10. Breaking Load of $\mathrm{Al}+$ fly ash composites

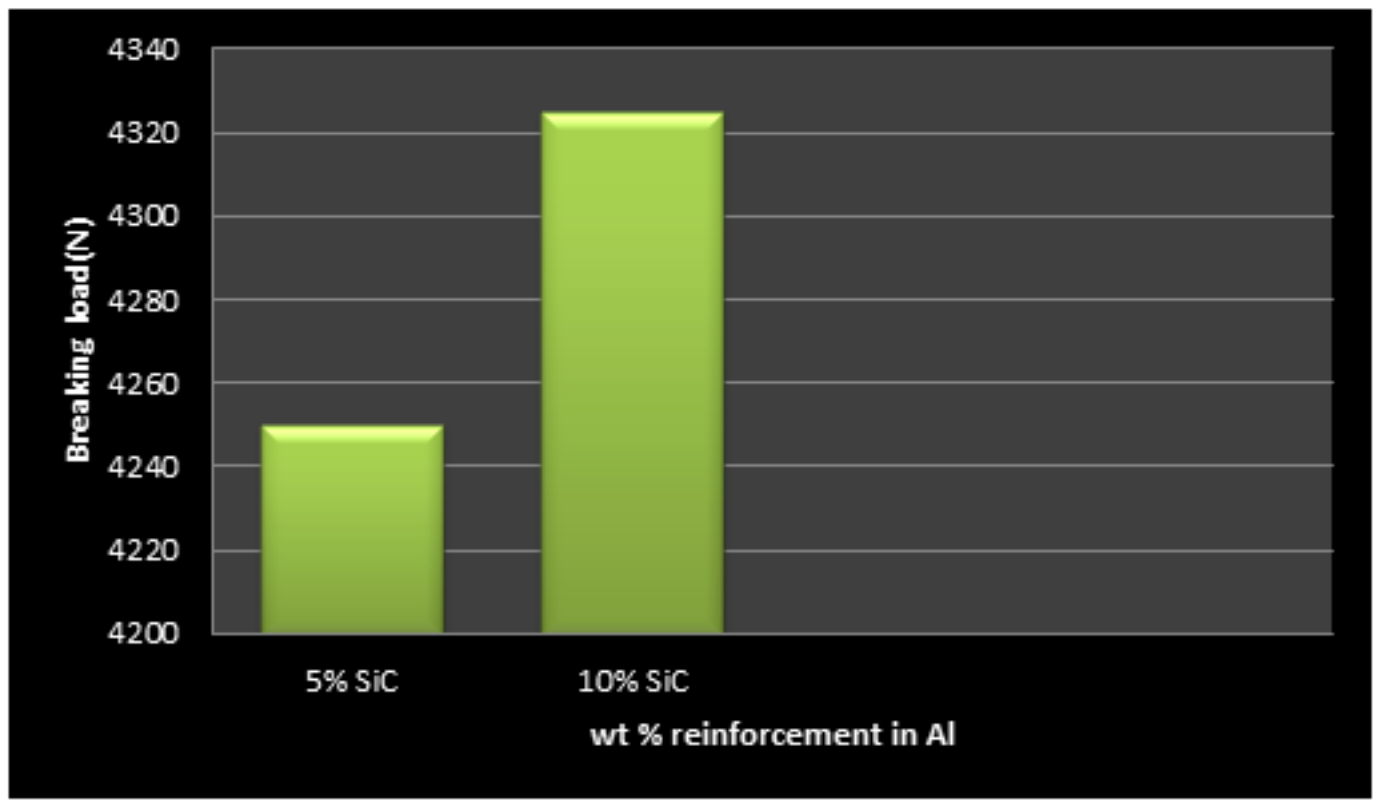

Figure 11. Breaking load of $\mathrm{Al}+\mathrm{SiC}$ composites 


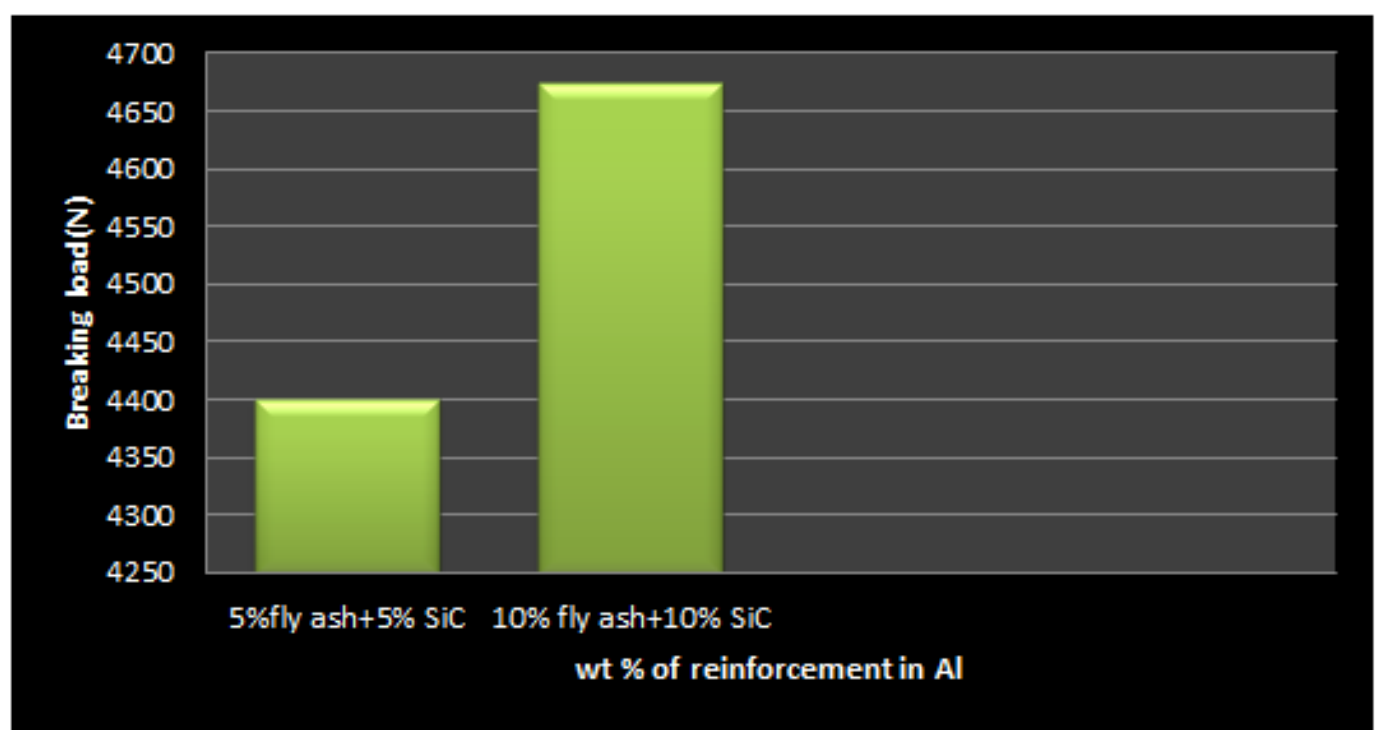

Figure 12. Breaking load of $\mathrm{Al}+$ fly ash $+\mathrm{SiC}$ composites

Figures 10, 11 and 12 indicate that when wt $\%$ of fly ash is increased the breaking load is decreased that means its tensile strength is increased.

\section{Conclusions}

The conclusions drawn from the present investigation are as follows:

1. Fly ash was successfully used for the fabrication of composites.

2. Fly ash and Silicon carbide up to $10 \%$ by weight were successfully added to $\mathrm{Al}$ by stir casting route to produce composites.

3. There was reduction in the frictional forces with the addition of fly ash in $\mathrm{Al}$ melt but the wear rates increases little bit. But the increase in wt $\%$ of silicon carbide was able to decrease both frictional forces and wear rates.

4. The hardness of $\mathrm{Al}+\mathrm{fly}$ ash, $\mathrm{Al}+\mathrm{SiC}$ composites was increased with increase in $\mathrm{wt} \%$ of fly ash and $\mathrm{SiC}$ But in case of $\mathrm{Al}+\mathrm{SiC}+\mathrm{fly}$ ash composites, the hardness was highly increased as compared to $\mathrm{Al}+\mathrm{fly}$ ash and $\mathrm{Al}+\mathrm{SiC}$ composites.

5. The Breaking load of Al+fly ash composites was found to be decreased with increase in wt $\%$ of fly ash. The breaking load of $\mathrm{Al}+\mathrm{SiC}+\mathrm{fly}$ ash composites was high as compared to $\mathrm{Al}+\mathrm{fly}$ ash composites and $\mathrm{Al}+\mathrm{SiC}$ composites.

\section{REFERENCES}

[1] A. K. Mishra, R. Sheokand, and R. Srivastava, "Tribological Behaviour of Al 6061/SiC Metal Matrix Composite by Taguchi's Techniques," International Journal of Scientific and Research Publications, vol. 2, p. 1, 2012.
[2] Y. Sahin, "Optimization of testing parameters on the wear behaviour of metal matrix composites based on the Taguchi method," Materials Science and Engineering: A, vol. 408, pp. 1-8, 2005.

[3] Y. Sahin, "Wear behaviour of aluminium alloy and its composites reinforced by $\mathrm{SiC}$ particles using statistical analysis," Materials \& design, vol. 24, pp. 95-103, 2003.

[4] M. Surappa, S. Prasad, and P. Rohatgi, "Wear and abrasion of cast Al-alumina particle composites," Wear, vol. 77, pp. 295-302, 1982.

[5] S. A. Sajjadi, H. Ezatpour, and M. T. Parizi, "Comparison of microstructure and mechanical properties of A356 aluminum alloy/Al 2 O 3 composites fabricated by stir and compo-casting processes," Materials \& Design, vol. 34, pp. 106-111, 2012.

[6] C. Cheung, K. Chan, and W. Lee, "Surface characterization in ultra-precision machining of $\mathrm{Al} / \mathrm{SiC}$ metal matrix composites using data dependent systems analysis," Journal of Materials Processing Technology, vol. 140, pp. 141-146, 2003.

[7] K. Kalaiselvan, N. Murugan, and S. Parameswaran, "Production and characterization of AA6061-B 4 C stir cast composite," Materials \& Design, vol. 32, pp. 4004-4009, 2011 .

[8] M. Surappa, "Dry sliding wear of fly ash particle reinforced A356 Al composites," Wear, vol. 265, pp. 349-360, 2008.

[9] M. Surappa, "Synthesis of fly ash particle reinforced A356 Al composites and their characterization," Materials Science and Engineering: A, vol. 480, pp. 117-124, 2008.

[10] A. K. Senapati, A. Bhatta, S. Mohanty, P. Mishra, and B. Routra, "An Extensive Literature Review on the Usage of Fly Ash as a Reinforcing Agent for Different Matrices," Int $J$ InnovSci Mod Eng, vol. 2, pp. 4-9, 2014.

[11] M. Singh, K. Goyal and D. K. Goyal, "Fabrication and Performance of Aluminium Based Metal Matrix Composites with $\mathrm{SiO}_{2}$ and $\mathrm{TiO}_{2}$ as Reinforced Particles," Universal Journal of Mechanical Engineering, Vol. 3 (4), pp. 142-146, 2015 . 